\title{
TWO BIOCHEMICAL ASPECTS OF CELL NECROSIS
}

\author{
BY \\ N. H. MARTIN \\ From the Department of Chemical Pathology, St. George's Hospital, London
}

In 1866, Hoppé Seyler was appointed to the Chair of Physiological Chemistry at the University of Tübingen, eight years after Virchow had published his lectures on cellular pathology. Buchner was no more than 6 years old at the time. Biochemistry, as we understand it, did not exist. To-day the dynamic approach which is the essential feature of modern biochemical teaching has produced advances in every biological field into which it has permeated.

The technical advances of the last three decades have given a much clearer picture of the anatomy of the giant molecules of which the living cell is built and through which it carries on its normal functions. Moreover, it is now possible to study to what extent and how fast the smaller units of which these giant molecules consist are built into the larger structure. This, if one likes to think of it, is anatomy and physiology at a molecular level. The natural extension of such studies is the examination of disease processes at a molecular level. By that one does not mean the movements of the electrolytes or the accumulations of such small units as urea or glucose, important as these are, but the changes in the character and concentration of the molecular units which comprise the cell itself. This is the logical extension of Virchow's cellular pathology.

In the general study of the cell's economy at molecular level one of the most active sections and one that is yielding the most rapid returns is the field of enzymology. Because some of the advances in this field have had direct clinical implications and because they are linked through histochemical studies to formal morbid anatomy it seemed apposite on this occasion to touch on this subsection of biochemistry. Two groups of enzymes, which will be familiar in name at least to all pathologists, have been picked at random for discussion. It is assumed that enzymes circulating in the serum have been elaborated in the cell and that with certain reservations fluctuations in serum levels mirror cellular changes. Indeed, Waterlow (1952) has produced some direct evidence to show that fluctuations in concentrations of circulating pseudocholinesterase parallel their concentrations in liver tissue.
However, two points must be borne in mind. It is obvious that one cannot assume that the changes in concentration in the circulation and in the tissue coincide. Moreover, if the apparent fall in circulating enzyme activity is due to an inhibitor incapable of penetrating the "cell membrane" there will be a discrepancy between cell and circulation so long as that inhibitor is effective.

\section{The Transaminases}

The transaminases are a large group of enzymes occurring throughout animal and plant tissues. They have interested biochemists for the last 20 years. Some 18 of these transaminases have been identified, of which two, the glutamate aspartate transaminase, more commonly called "glutamate oxalacetic transaminases" (G.O.T.), and the glutamate alarine transaminases, more commonly called "glutamate pyruvate transaminases" (G.P.T.), are of particular interest to the chemical pathologist. The chemical reactions involved are shown in Fig. 1. Both enzymes required phosphopyridoxal as a co-factor. Cohen and Hekhuis noted the high concentration of G.O.T. in cardiac muscle as long ago as 1941 . But it was not until 1955 that LaDue and Wróblewski noted that when the heart muscle was injured there was a release of sufficient glutamate oxalacetic transaminase to produce a rise in blood levels.

Table I shows the relative concentrations of glutamate oxalacetic transaminase in tissue from data of Dubach (1957). It will be seen that myocardium is twice as rich in the enzyme as the liver or skeletal muscle and 50 times as rich as lung tissue. However, since skeletal muscle represents

TABLE I

CONCENTRATIONS OF GLUTAMIC OXALACETIC

\begin{tabular}{|c|c|c|c|c|c|}
\hline & & & & & $\begin{array}{c}\text { Units per g. of } \\
\text { Homogenized Tissue }\end{array}$ \\
\hline 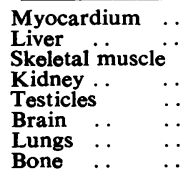 & $\begin{array}{l}\cdots \\
\ldots \\
\cdots \\
\cdots \\
\cdots \\
\ldots\end{array}$ & $\begin{array}{l}\cdots \\
\cdots \\
\cdots \\
\cdots \\
\cdots \\
\cdots\end{array}$ & $\begin{array}{l}\cdots \\
\cdots \\
\cdots \\
\cdots \\
\cdots \\
\cdots\end{array}$ & $\begin{array}{l}\cdots \\
\cdots \\
\cdots \\
\cdots \\
\cdots \\
\cdots \\
\cdots\end{array}$ & $\begin{array}{c}300,000 \\
159,000 \\
135,000 \\
83,000 \\
78,000 \\
38,000 \\
6,500 \\
\text { None found }\end{array}$ \\
\hline
\end{tabular}

From data of Dubach (1957). 


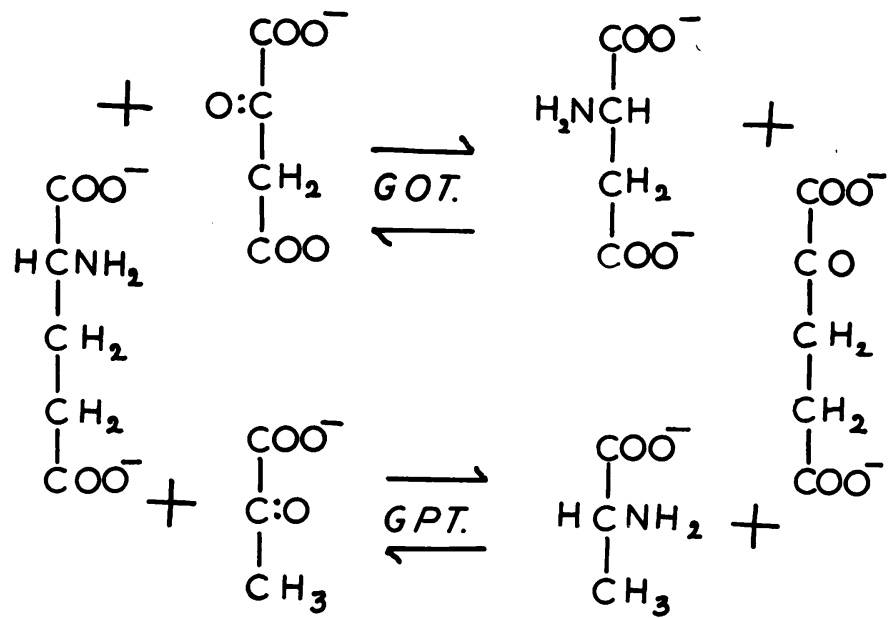

Fig. 1.-Above : the transfer of the amine group under the influence of glutamate oxalacetic transaminase, upper pathway. Below: glutamate-pyruvic transaminase-lower pathway.

about $40 \%$ of the total body weight it is, in practice, the richest reservoir of the transaminase enzyme. Indeed, in the "crush syndrome" seen so commonly in the war of 1939 to 1945 , which resulted from extensive necrosis of voluntary muscle, it is very probable that levels of circulating transaminase were very high in the 48 hours following injury. Shabetai, Iglauer, and Anderson (1957) record one patient with acute pancreatitis who had a serum amylase level of 1,600 units and a serum transaminase level of 238 units.

Fig. 2 shows a plot of the level of the glutamate oxalacetic transaminase following acute myo-

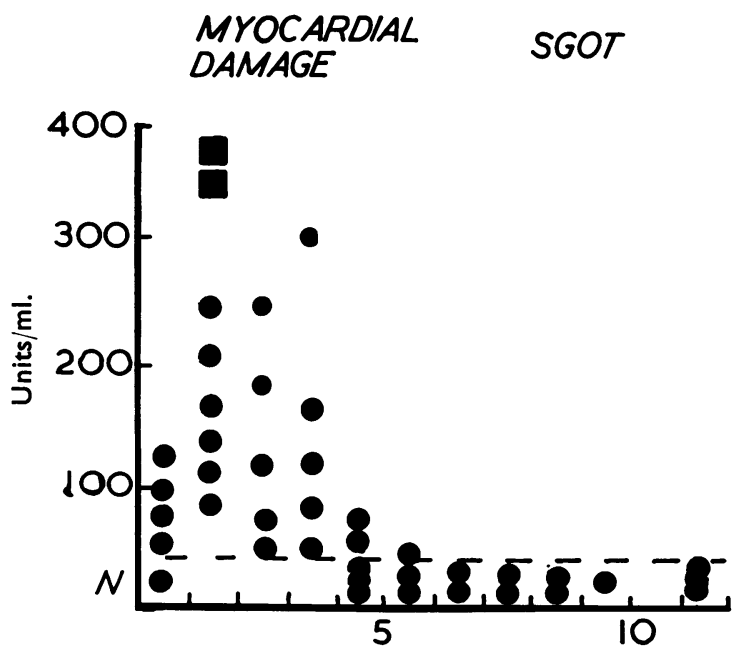

DAYS.

FIG. 2.-Glutamate oxalacetic transaminase levels following acute myocardial infarction. The black squares record two deaths. cardial necrosis of varying degrees of severity from our own material and from the data of Shabetai et al. and of Dubach. It will be seen that within 24 hours of myocardial damage there is a significant rise in the level of the circulating enzyme which is usually maximal by the second day, falling away rapidly again on the third or fourth day. Usually the circulating level has dropped to normal by the sixth day if there is no extension of the necrotic process.

If one assumes that the normal level of circulating G.O.T. is 40 units per minute, then the destruction of $1 \mathrm{~g}$. of myocardium should raise the level of circulating transaminase to about 80 to 100 units per minute. Moreover, the destruction of a fifth of a gram should produce a detectable rise in the level of the circulating enzyme. That is roughly equivalent to $0.1 \%$ of the total mass of the heart. Naive calculations of this type are fraught with error, but they are useful if they stimulate thought.

Where it has been possible to make observations it appears that significant rises in circulating transaminase level do not occur much within 10 hours of the primary myocardial insult. Chinsky, Shmagranoff, and Sherry (1956) claim that $50 \%$ of patients with levels about 200 units die in the attack. The experimental work of Nydick, Wróblewski, and LaDue (1955) suggests that unless the myocardial ischaemia is sufficient to produce necrosis no rise in circulating transaminase can be demonstrated.

Where values have returned to normal, fresh infarction may be associated with a second rise in the level of the circulating enzyme, and it is this as well as the help the estimation gives in assessing various forms of retrosternal pain that gives this estimation its special value.

Here then is an example of an enzyme study which may from time to time be of very real use in the practice of medicine.

In the table of tissue concentrations it was noted that the liver was another organ rich in the glutamate oxalacetic transaminase. The liver is also rich in the glutamate pyruvic transaminase, another member of the same enzyme group. It is not surprising that recent studies of serum transaminase levels in various types of acute liver damage suggest a close relationship between the two. Fig. 3 shows serial studies of the serum levels of both enzymes during the course of attacks 


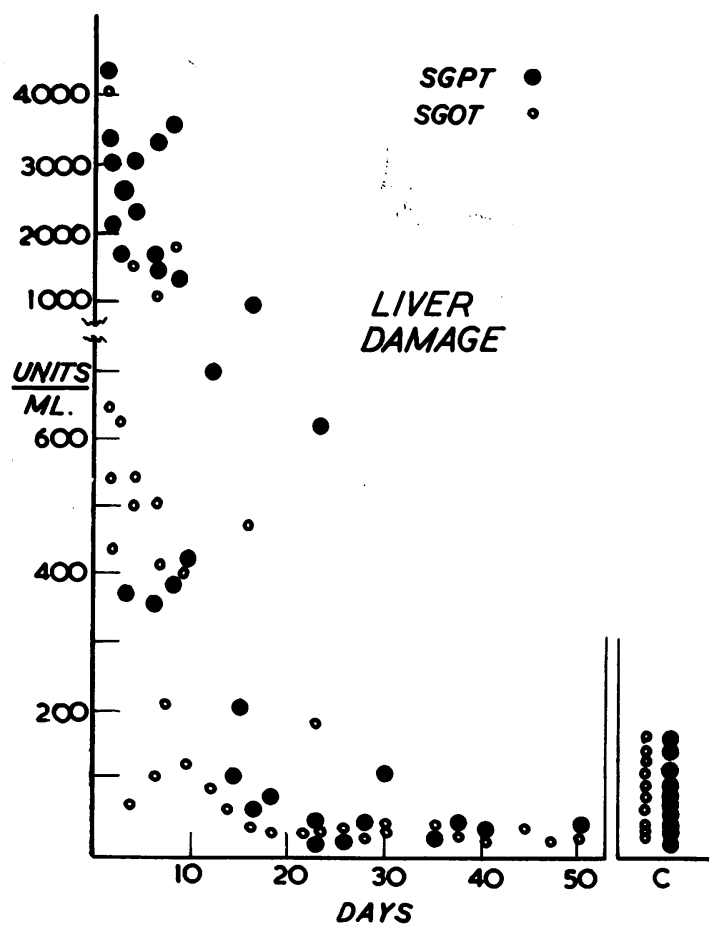

FIG. 3.-Transaminase levels in acute and chronic hepatitis. (" C"= chronic.)

of infective hepatitis from data by Henry in the St. George's Hospital laboratory. It is evident that the levels reached of the glutamate pyruvic acid enzyme are much higher on average than of the glutamate oxalacetic enzyme. Moreover, the levels recorded are already very high in the earliest stages at which clinical diagnosis is normally feasible and fall only gradually over the next 10 to 30 days.

Chinsky, Wolff, and Sherry (1957) demonstrated that the serum glutamate pyruvic transaminase levels were not elevated in myocardial damage in contrast with various forms of acute liver damage. Pryse-Davies and Wilkinson (1958), in a careful study of the diagnostic value of transaminase values in liver damage, found that they were raised in the early stages of hepato-cellular damage regardless of aetiology. They quote a patient who underwent a partial hepatectomy whose transaminase level was 800 units immediately following section, falling almost to normal limits by the sixth post-operative day.

Henry tested the sera from a number of patients with acute hepatitis and some who were known to have chronic liver damage (Fig. 3). The estimates were made when the patients were not in acute clinical relapse. It will be seen that the values were often raised, but never to the levels seen in acute hepatitis. Henry, like Pryse-Davies and Wilkinson (1958), found occasional normal values in cirrhotics. We would like to suggest that in chronic liver damage the elevated S.G.P.T. levels are indicative of a recrudescence of active liver cell destruction, whereas the normal values indicate a " resting" phase. If this view is correct, in following through a patient with relapsing progressive hepatitis we should observe a coincident waxing and waning of the transaminase level.

It is worth stressing that some of the methods of estimation are not highly specific and tend to fall off in their quantitative accuracy at ranges much above 1,000 units $/ \mathrm{ml}$. They seem porfectly adequate for routine chemical pathological practice. Pryse-Davies and Wilkinson (1958) have pointed out the effect of temperature on quantitative values obtained.

These then are two enzymes of a large and widespread group of intracellular enzymes which are sufficiently robust to survive the death and disintegration of the cells in which they normally function, enzymes whose release and time of survival in the blood stream give useful clinical information.

\section{The Serum Cholinesterases}

The detailed comparison of the red cell cholinf esterases and the serum cholinesterases was made by Alles and Hawes (1940) 18 years ago. Adams and Whittaker (1949) and Whittaker (1951) compared the substrate specificity of the two groups of enzymes and on the basis of their findings proposed the name "butyro choline

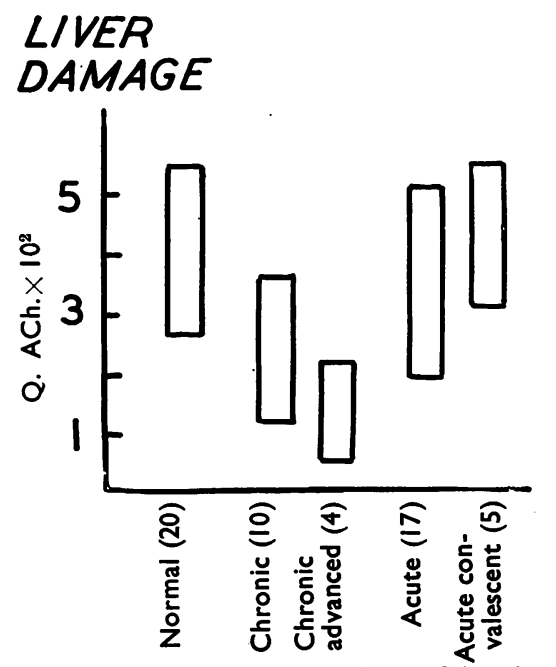

FIG. 4.-Cholinesterase levels in various forms of liver damage. $(\mathrm{Q}=$ enzyme activity in terms of total serum protein nitrogen.) 


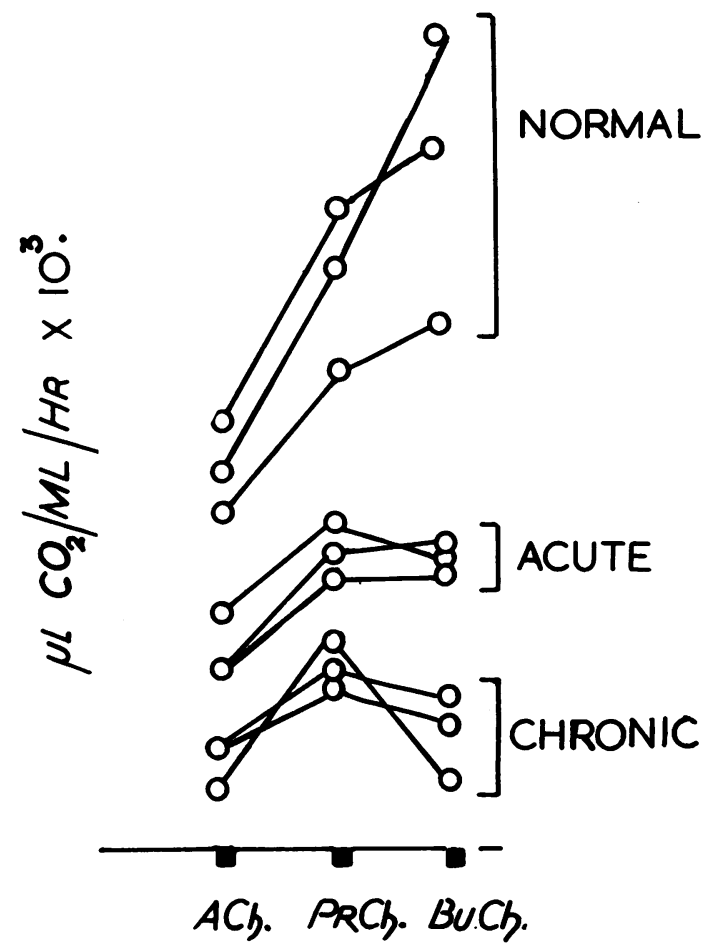

FIG. 5.-The differential esterase substrate pattern in acute and chronic liver disease after Kekwick (1955).

esterase" for the serum esterase commonly referred to as pseudocholinesterase. McArdle in 1940 had shown that the levels of serum cholinesterase decreased in patients suffering from liver damage, and many workers have confirmed his observations. Fig. 4 tabulates some results obtained by Kekwick (1955) when he was working on the esterases and their purification four years ago at St. George's Hospital. It will be seen that, unlike the transaminases, liver damage is associated with a drop in the levels of circulating "butyro esterase" activity and that this drop is most striking in patients with advanced chronic liver damage. It occurred to Kekwick to examine whether the fall in activity was associated with a change in the substrate pattern which Whittaker and his co-workers had described. Fig. 5 shows some of the results. There is an alteration in specific substrate pattern. This alteration could be the result of selective failure of the liver to produce a specific enzyme, the original pattern in fact representing a com- posite of enzyme activities, or that, as a result of continuous insults, the liver cell is failing to produce the "butyro esterase" in its final normal configuration, and releasing instead a "brokenbacked" enzyme, the product of an incompetent cell. We know that in liver damage there is a quantitative failure: does this work of Kekwick's suggest a qualitative failure ?

These are only two examples of the practical and potential value of enzyme studies in disease processes. There are many more-the phosphatases, the lipases, the dehydrogenases, to mention only a few. As our detailed knowledge of protein structure develops we shall undoubtedly be able to develop more exact knowledge of the mechanics of enzyme behaviour, for it is important to remember that to a large extent the enzymologist is not studying structure directly so much as behaviour patterns. $\mathrm{He}$ is the molecular psychologist. The specific capacity to nydrolyse an ester or group of esters is a function of an area and not of the whole molecule, though the integrity of the whole may be essential if the individual activity is to be maintained at a rate that enables it to be correctly integrated in the total activity of the cell.

Failure of integration is one aspect of the disease process as surely as any morphological change observed by histological techniques. But there is a long road ahead. As Kossel has said, the amino-acids that compose the protein molecule are as numerous as the letters of the alphabet and these are capable of expressing an infinite number of thoughts.

I wish to acknowledge financial assistance from the free funds of St. George's Hospital in carrying out part of the research referred to in this article.

\section{REFERENCES}

Alles, G. A., and Hawes, R. C. (1940). J. biol. Chem., 133, 375 Adams, D. H., and Whittaker, V. P. (1949). Biochim. Biophys. Acta, 3,358

Chinsky, M., Shmagranoff, G. L., and Sherry, S. (1956). J. Lab. clin. Med., 47, 108 .

Wolff, R. J., and Sherry, S. (1957). Amer. J. med. Sci., 233, 400 Cohen, P. P., and Hekhuis, G. L. (1941). J. biol. Chem., 140, 711.

Dubach, U. C. (1957). Helv. med. Acta, $24,357$.

Kekwick, R. G. O. (1955). Ph.D. thesis, University of London.

Kekwick, R. G. O. (1955). Ph.D. thesis, University of London.

LaDue, J. S., and Wróblewski, F. (1955). Circula
McArdle, B. (1940). Quart. J. Med., n.s., 9, 107.

Nydick, I., Wróblewski, F., and LaDue, J. S. (1955). Circulation, 12, 161 .

Pryso-Davies, J., and Wilkinson, J. H. (1958). Lancet, 1, 1249.

Shabetai, R., Iglauer, A., and Anderson, D. M. (1957). Brit. med. J.,

1,555 .
Waterlow, J. C. (1952). Transactions of the 11th Conference on Liver Injury, p. 90. Josiah Macy Jr. Foundation, New York. Whittaker, V. P. (1951). Physiol. Rev., 31, 312. 